\title{
BONE AS A SODIUM AND POTASSIUM RESERVOIR ${ }^{1,2}$
}

\author{
By WILLIAM H. BERGSTROM \& AND WILLIAM M. WALLACE \\ (From the Department of Pediatrics, Harvard Medical School, and the Children's Medical \\ Center, Boston, Mass.)
}

(Submitted for publication November 24, 1953 ; accepted February 18, 1954)

Gamble, Ross, and Tisdall (1) originally pointed out that electrolytes and water were lost from the body during fasting in a manner which could be reasonably predicted from the concentration of salts in the body fluids. This concept is the basis for the study of changes in body composition by examination of electrolyte balance and weight changes. Darrow, Da Silva, and Stevenson (2) elaborated the method of calculation and showed that shifts of sodium between extracellular and intracellular fluid could be inferred in certain conditions from balance measurements. In this laboratory, studies in both man and animals $(3,4)$ have frequently demonstrated losses or gains of sodium which cannot be reasonably explained on the basis of shifts so calculated. Two possible explanations are: (a) Unmeasured skin losses may lead to the calculation of erroneously large retentions, or (b) Electrolyte may be sequestered in the body in an osmotically inactive form quickly available to the body fluids. Flanagan, Davis, and Overman (5), studying both balances and composition of tissues in dogs with adrenal insufficiency, noted such discrepancies and suggested that bone might serve as a sodium reservoir.

The early work of Gabriel (6) demonstrated the presence of substantial amounts of sodium in the chloride-free residue of bone extracted with alkaline glycol solutions. Harrison, Darrow, and Yannet (7) showed that the ratio of sodium to chloride in the skeleton is greatly in excess of that found in a plasma ultrafiltrate, and defined this as "extra" bone sodium. Subsequent investigators have confirmed these findings $(8,9)$, and Kaltreider, Meneely, Allen, and Bale (8), Stern, Cole, Bass, and

1 This investigation was supported in part by grants from the National Research Council and from the National Heart Institute of the National Institutes of Health, Public Health Service.

2 Presented at the meeting of the American Society for Clinical Investigation at Atlantic City, N. J., May, 1952.

8 Fellow in the Medical Sciences of the National Research Council, 1951-52.
Overman (10), and Edelman, James, and Moore (11), using radioactive isotopes, have shown that approximately 40 per cent of bone sodium is exchangeable with circulating radiosodium within 24 hours.

The chemical relationships of sodium and potassium to the crystal lattice of bone are not surely known. Neuman and associates (12) consider bone to have the general formula of a multiple apatite, $\mathrm{Ca}_{2}\left(\mathrm{PO}_{4}\right)_{0} \cdot \mathrm{CaX}_{2}$. Their experimental data indicate that, under physiologic conditions, $\mathrm{CO}_{2}$ appears to be bound to the $\mathrm{X}$ positions of such $\mathrm{a}$ salt by a single bond-i.e., as bicarbonate. They point out, however, that $\mathrm{CO}_{2}$ may actually be present as carbonate because of secondary ionization of such a complex: $-\mathrm{Ca}-\mathrm{O}-\mathrm{C}-\mathrm{O}_{2}-\mathrm{H}+\mathrm{Na}^{+}$ $\left(\right.$ or $\left.\mathrm{K}^{+}\right) \rightleftharpoons-\mathrm{Ca}-\mathrm{O}-\mathrm{C}-\mathrm{O}_{2}-\mathrm{Na}(\mathrm{K})+\mathrm{H}^{+}$. $\mathrm{Ex}-$ perimental work by one of the authors (13) is in keeping with the concept of secondary ionization.

One of the implications of this concept of the nature of the binding of sodium and potassium to the mineral portion of bone is that the crystal lattice may act as an ionic exchanging area capable of donating sodium ions to the body fluids in exchange for hydrogen ions during periods of acidosis. Since skeletal sodium accounts for approximately a third of the total body sodium (8-10), an investigation of its role in this regard seemed desirable. The experiments to be described here were undertaken to determine the effect of acidosis and of sodium deprivation on the relative quantities of sodium, potassium and calcium in bone.

\section{EXPERIMENTAL PROCEDURE}

Acute sodium depletion and acidosis were induced in albino rats (Lansing strain) by intraperitoneal dialysis against a solution containing $50 \mathrm{Gm}$. of glucose and 90 mM. of ammonium chloride per liter. The amount injected intraperitoneally was $10 \mathrm{ml}$. per $100 \mathrm{Gm}$. of body weight. Four hours after injection as much peritoneal fluid as possible was withdrawn. The amount obtained usually exceeded that injected. The animals were then allowed water ad libitum but no food in order to pre- 
vent access to exogenous base. After 48 hours the animals were sacrificed.

Chronic sodium deprivation was achieved by raising weanling rats on a synthetic sodium-free diet. The composition of the control ration was that used by Cotlove, Holliday, Schwartz, and Wallace (14); the experimental animals were given the same diet with ammonium ion substituted for sodium in the salt supplement. All of the rats in this series received the complete diet for one week; the experimental group was then given the sodiumfree diet and the controls continued on the complete ration. After a two-week experimental period, all animals were sacrificed.

At the time of sacrifice, blood was withdrawn from the aorta for serum analyses. All of the long bones of each animal were removed, freed of periosteum and epiphyses and weighed.

\section{CHEMICAL METHODS}

A. Bone: (1) Water was taken to be the difference between fresh wet weight and dry weight after 48 hours at $105^{\circ} \mathrm{C}$. The dried bone was ground in a mortar and the powder used for subsequent analyses. (2) Chloride was determined in duplicate aliquots of dry powder by an adaptation of the method of Sunderman and Williams (15) to semi-micro quantities. (3) Sodium and Potassium were measured using an internal standard flame photometer (16). The very high ratio of calcium to sodium in bone precludes accurate analysis of the sodium even when the internal standard is used. Sodium must be quantitatively separated from calcium for analysis. One hundred to $200 \mathrm{mg}$. of dry bone powder was ashed in a platinum vessel at $550^{\circ} \mathrm{C}$. The ash was dissolved in $11 \mathrm{ml}$. of 10 per cent nitric acid and $5 \mathrm{ml}$. aliquots were transferred to $40 \mathrm{ml}$. centrifuge tubes. Five $\mathrm{ml}$. of 5 per cent oxalic acid and $10 \mathrm{ml}$. of water were added and the pH. brought to 8-9 (bromthymol blue) by running in 3 to $4 \mathrm{ml}$. of concentrated $\mathrm{NH}_{4} \mathrm{OH}$ from a burette. Appreciable quantities of sodium co-precipitate with calcium under these conditions (17), so that repeated precipitations are required for separation. The tubes were allowed to stand overnight and, after centrifugation, the supernatant fluid was transferred to a volumetric flask. The precipitate was then re-dissolved in nitric acid and the process twice repeated. The supernatant fluids from all three precipitations were combined in the same volumetric flask, to which an appropriate quantity of lithium was added before flame photometry was carried out. This method, when applied to solutions containing weighed amounts of sodium, potassium, calcium, magnesium, and phosphorus in the proportions appropriate for bone ash, gave recovery values for sodium and potassium within 1 per cent of the known values. Analysis of multiple aliquots of bone powder indicated reproducibility within plus or minus 4 per cent. It was found necessary to use a reagent blank with each set of determinations, since the C.P. grade nitric acid and ammonium hydroxide used contained significant amounts of sodium and potassium even when redistilled in Pyrex glassware. (4) Calcium was measured by permanganate titration of the precipitate left from the sodium and potassium analysis, after washing twice with 2 per cent ammonium hydroxide to remove excess oxalate (18). Accuracy and reproducibility were found to be within 1 per cent.

B. Serum: (1) Sodium and Potassium were measured with the flame photometer, using methods previously described in this laboratory (16). (2) Chlorides were done in duplicate by the iodometric method of Van Slyke and Hiller (19). (3) Serum $p H$ was determined by the method of Hastings and Sendroy (20). (4) Total serum $\mathrm{CO}_{2}$ was determined by the method of Van Slyke and Neill (21).

\section{CalCULATIONS}

Values for all constituents were expressed as mEq. per kilogram of fresh bone. Chloride was assumed to be extracellular. On this basis, bone water was divided into extracellular and intracellular compartments using Donnan-corrected serum chloride concentrations and total bone chloride values. Total bone sodium was then corrected by subtracting the amount of sodium calculated to be present in the extracellular phase. The remainder was regarded as "extra" bone sodium as originally defined by Harrison, Darrow, and Yannet (7). Intracellular water, as approximated above, was arbitrarily assigned a potassium concentration of $150 \mathrm{mEq}$. per liter. Total bone potassium was corrected for intracellular potassium thus estimated, and the remainder was taken to represent "extra" potassium, analogous to "extra" sodium. The necessity for assuming rather than measuring the potassium concentration of bone marrow cell water is an admitted source of error. The small amount of marrow available in the rat and the technical difficulty of securing sufficient material for analysis without evaporation dictated the compromise.

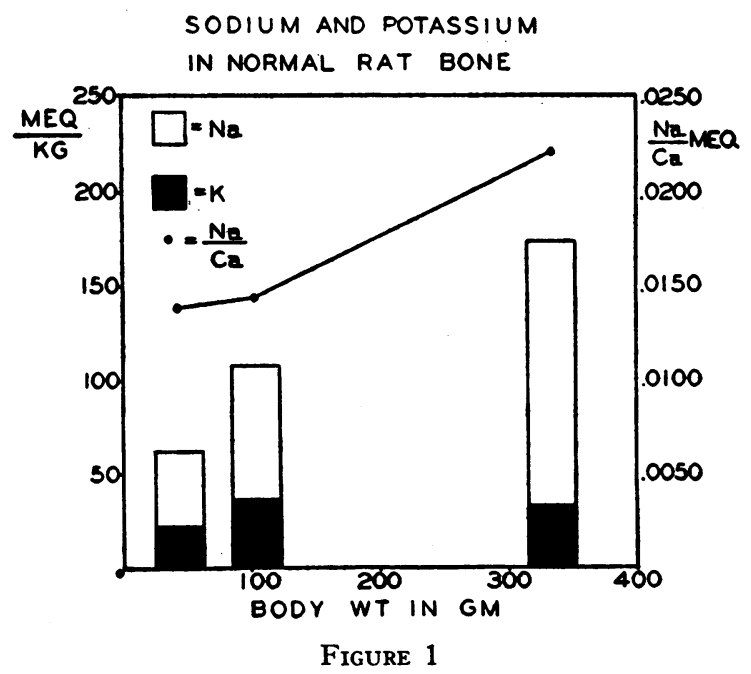


TABLE I

Bone and serum electrolyte data, normal, acidotic and low sodium animals

\begin{tabular}{|c|c|c|c|c|c|c|c|c|c|c|c|c|c|}
\hline \multirow{3}{*}{ Group* } & \multirow{3}{*}{ Av. wt. } & \multicolumn{8}{|c|}{ Bone } & \multicolumn{4}{|c|}{ Serum $\ddagger$} \\
\hline & & \multicolumn{2}{|c|}{ Na. $m E q . / K g}$. & \multicolumn{2}{|c|}{$\mathrm{K}, \boldsymbol{m E q} . / K_{\mathrm{g}}$} & \multirow[b]{2}{*}{$\mathbf{C a}$} & \multirow[b]{2}{*}{$\mathrm{Cl}$} & \multirow{2}{*}{$\mathrm{Na} / \mathrm{Ca}$} & \multirow{2}{*}{$\mathrm{K} / \mathrm{Ca}$} & \multirow{2}{*}{$\begin{array}{l}\mathrm{pHs} \\
38^{\circ}\end{array}$} & \multirow{2}{*}{$\mathrm{CO}_{2}$} & \multirow{2}{*}{$\mathrm{Na}$} & \multirow{2}{*}{$\mathrm{Cl}$} \\
\hline & & Total & Corr. & Total & Corr. & & & & & & & & \\
\hline \multirow{2}{*}{$\begin{array}{l}\text { Normal Adults } \\
\text { (14 Rats) } \\
\text { S.E. }\end{array}$} & $\begin{array}{l}G m . \\
333\end{array}$ & 206 & 173 & 43 & 30 & $\begin{array}{c}m E q . / \\
K_{\ell} \\
8000\end{array}$ & $\begin{array}{c}m E q . / \\
K_{8} \\
25\end{array}$ & .0218 & .0028 & 7.33 & $\begin{array}{l}m M . / \\
L . \\
26.3\end{array}$ & $\begin{array}{c}m E q . / \\
L . / \\
148\end{array}$ & $\begin{array}{c}m E q . / \\
L . \\
109\end{array}$ \\
\hline & & 6.2 & 5.7 & & & 313 & & .0005 & .0003 & $\begin{array}{l}.02 \\
(8)\end{array}$ & $\begin{array}{l}1.2 \\
(8)\end{array}$ & & \\
\hline \multirow{2}{*}{$\begin{array}{l}\text { Acidotic Adults } \\
\text { (14 Rats) } \\
\text { S.E. } \\
\text { P }\end{array}$} & 265 & 154 & 119 & 22 & 10 & 7800 & 26 & .0152 & .0013 & 7.20 & 20.9 & 138 & 97 \\
\hline & & 7.1 & $\begin{array}{c}6.7 \\
.01\end{array}$ & & $\begin{array}{c}1.9 \\
.01\end{array}$ & ${ }^{165} .6$ & & $\begin{array}{l}.0007 \\
.01\end{array}$ & $\begin{array}{l}.0002 \\
.01\end{array}$ & $\begin{array}{l}.02 \\
.01 \\
(8)\end{array}$ & $\begin{array}{l}0.3 \\
.01 \\
(8)\end{array}$ & & \\
\hline \multirow{2}{*}{$\begin{array}{l}\text { Normal Juvenile } \\
\text { (8 Rats) } \\
\text { S.E. }\end{array}$} & 103 & 157 & 108 & $54 \dagger$ & $34 t$ & 7500 & 36 & .0145 & .0055 & & & 159 & 107 \\
\hline & & 7.6 & 8.4 & & & 203 & & .0012 & & & & & \\
\hline \multirow{2}{*}{$\begin{array}{l}\text { Acidotic Juvenile } \\
\text { (6 Rats) } \\
\text { S.E. } \\
\text { P }\end{array}$} & 109 & 139 & 87 & $44 \dagger$ & $27 \dagger$ & 6200 & 34 & .0139 & .0044 & & & 157 & 97 \\
\hline & & 5.8 & $\begin{array}{c}5.8 \\
.05\end{array}$ & & & $\begin{array}{l}174.01 \\
\quad .01\end{array}$ & & & & & & & \\
\hline $\begin{array}{l}\text { Weanling } \\
\text { (3 Rats) }\end{array}$ & 43 & & 62 & & 21 & 4400 & 36 & .0140 & .0047 & & & & \\
\hline \multirow{2}{*}{$\begin{array}{c}\text { Low Sodium } \\
\text { Controls } \\
\text { (7 Rats) } \\
\text { S.E. }\end{array}$} & 141 & 154 & 125 & 99 & 58 & 6100 & 24 & .0208 & & & & 153 & 106 \\
\hline & & 13 & 13 & 10 & 7 & 165 & & .0027 & & & & & \\
\hline \multirow{2}{*}{$\begin{array}{c}\text { Low Sodium } \\
\text { (8 Rats) } \\
\text { S.E. } \\
\text { P }\end{array}$} & 109 & 91 & 64 & 43 & 5 & 6100 & 21 & .0105 & & & & 148 & 105 \\
\hline & & 8 & ${ }^{8} .01$ & 8 & ${ }^{5} .01$ & 222 & & $\begin{array}{l}.0013 \\
.05\end{array}$ & & & & & \\
\hline
\end{tabular}

* S.E. and $P$ are calculated according to Fisher's $t$ test.

$\dagger$ Data for 4 rats only. group.

I Numbers in parentheses indicate number of observations where this differs from number of rats in experimental

\section{RESULTS}

Normal values are shown in the table and in Figure 1. Sodium and potassium contents are corrected as explained above and are expressed as $\mathrm{mEq}$. per kilogram of fresh wet bone; the ratio of each of these cations to calcium in $\mathrm{mEq}$. is also shown. Harrison used the latter method of notation to distinguish between changes in bone salt composition (22). The chart and tables show that bone sodium increases with increasing body size. The absolute increase in sodium (from 62 to 173 $\mathrm{mEq}$. per $\mathrm{Kg}$.) is greater than the increase in the $\mathrm{Na} / \mathrm{Ca}$ ratio $(.0140$ to .0220$)$. This is to be expected, since it is known (23) that the ash content of bone is greater in older animals. The change in ratio is consistent with previous demonstrations of change in bone salt composition with age $(23,24)$. The average corrected sodium content was 173 $\mathrm{mEq}$. per kilogram in adult $(333 \mathrm{Gm}$.) rats; in juvenile $(103 \mathrm{Gm}$.) rats it was $108 \mathrm{mEq}$. per kilogram. Corresponding potassium values were 30 and $34 \mathrm{mEq}$. per kilogram.

The results of dialysis against ammonium chloride are shown in Table $I$ and illustrated in Figures 2 and 3 . This procedure produced a moderate degree of acidosis as evidenced by significant decreases in serum $\mathrm{pH}$ and total carbon dioxide in the adult-sized animals. Determination of the serum acid-base pattern of the smaller animals is technically difficult and no data are available to document acidosis in the juvenile group. Analysis of the dialysate after withdrawal indicated that approximately $15 \mathrm{mEq}$. of sodium per kilogram of 


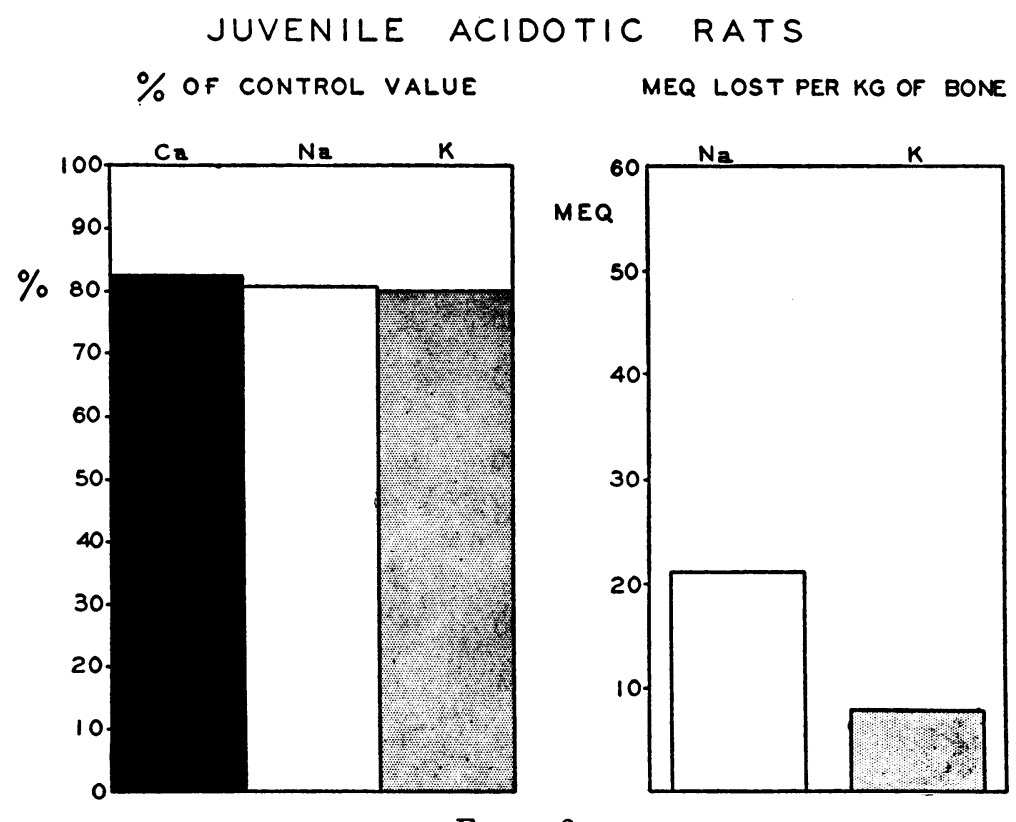

Figure 2

body weight were removed from the body by this procedure. The average value for total body sodium in the rat is $60 \mathrm{mEq}$. per kilogram of fat free weight (25). In the juvenile group the procedure resulted in the loss of $21 \mathrm{mEq}$. of sodium and 7 $\mathrm{mEq}$. of potassium per kilogram of bone; a proportionate loss of calcium occurred and there was no significant change in the ratio of either cation to calcium. In the adult group there was a loss of $54 \mathrm{mEq}$. of sodium and $20 \mathrm{mEq}$. of potassium per kilogram of bone. The change in calcium (200 mEq. or 2.5 per cent) was not significant. The $\mathrm{Na} / \mathrm{Ca}$ ratio decreased from .022 to $.015 ; \mathrm{K} / \mathrm{Ca}$ from .003 to .001 . The reason for the difference in reaction of the two groups of animals is not apparent. It has been found that shaft bone sam-

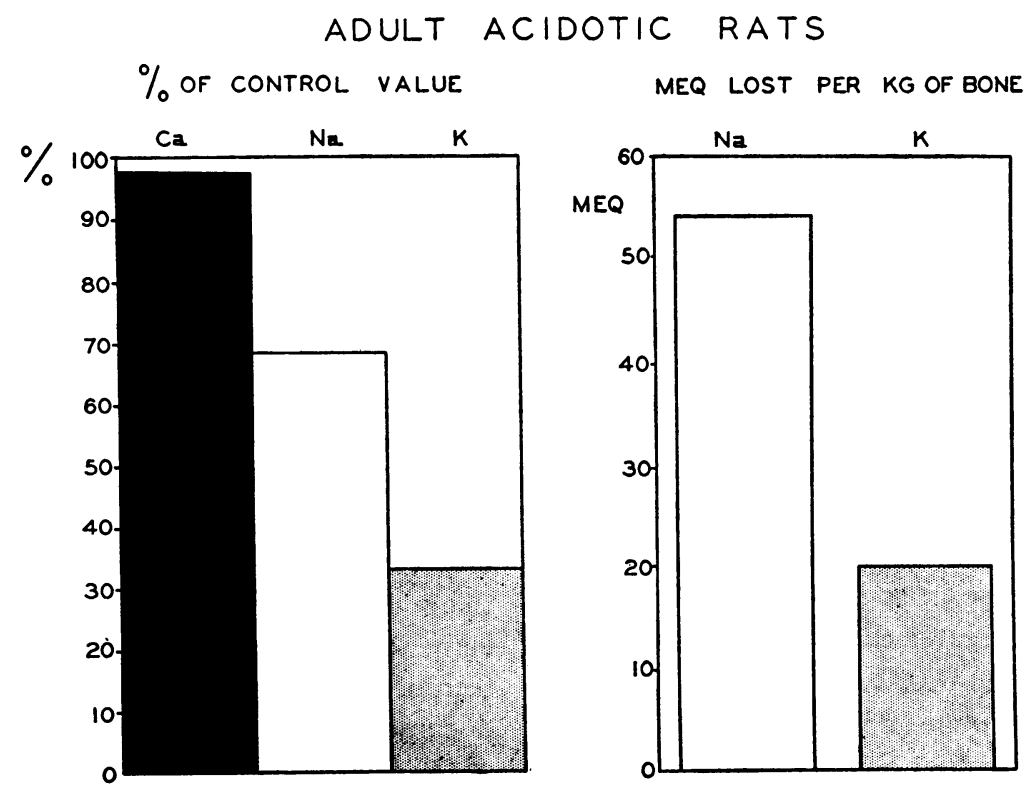

FIGURE 3 
ples from young animals have a much more rapid turnover of calcium and phosphorus than corresponding samples from mature animals (12). This suggests that the proportion of bone salt accessible as a source of base may be greater in young animals than in older ones.

The last two groups of animals shown in Table I indicate the effect of chronic dietary sodium ion deprivation on the composition of the bone of rapidly growing animals. The concentration of calcium in the bones of the control and low sodium group are equal indicating little interference with the deposition of this ion. The concentration of sodium is 50 per cent lower in the experimental group than in the controls. An even greater change in the concentration of potassium is evident. The decrease in concentration of potassium in the face of an adequate dietary intake is explained by the fact that diets low in sodium, if they are normal in respect to other ions, contain inadequate quantities of cation to enable full renal regulation of acid-base balance. The effects of a low sodium ion diet cannot, therefore, be differentiated from those of fixed anion excess.

\section{DISCUSSION}

Rapid changes in the chemical composition of bone are known to occur during metabolic disturbances. In 1933, Irving and Chute (26) found that bone lost substantial amounts of carbonate in rats and guinea pigs undergoing acute acid loads. After four days of oral $\mathrm{HCl}$ administration, their experimental animals showed a decrease in bone carbonate of $7 \mathrm{mEq}$. per kilogram of body weight, which is equivalent to approximately $70 \mathrm{mEq}$. per kilogram of bone, since fresh skeletal weight is equal to 10 per cent of body weight in the rat (27). Brooke, Smith, and Smith (28) showed a low salt content in the bones of rats fed on a diet poor in inorganic constituents and noted that the calcium lost on the salt-poor ration ". . . is provided to a greater extent from the carbonate of bone than from phosphate." More recently, Sobel, Rockenmacher, and Kramer (29) found that the calcium to carbonate ratio of bone ash could be changed in rats by altering the serum phosphorus to carbonate ratio.

In 1934, Orent, Kruse, and McCollum (30) studied changes in bone and serum magnesium in weanling rats raised on a magnesium deficient diet. They observed acute lowering of bone magnesium and elevation of serum magnesium when convulsions were induced in the deficient animals. Duckworth and Godden (31) later concluded that the skeleton constitutes the main magnesium reserve of the body and that skeletal magnesium is highly labile. They found that magnesium was more readily mobilized in animals which were deficient in calcium as well as magnesium, and stated that the availability of skeletal magnesium was inversely proportional to the rate of bone growth.

These observations indicate that the composition of bone salt is not fixed, but reflects the state of chemical equilibrium in the body. Severe disturbances in acid-base balance or in the supply of certain electrolytes are reflected in altered bone salt composition. Hence, it is not surprising that significant amounts of sodium and potassium should be mobilized from the skeleton under appropriate circumstances. The earlier investigations mentioned above show that such mobilization may occur without general dissolution of the crystal lattice, i.e., that it may be selective. This is confirmed by the results of the present study, which indicate altogether disproportionate changes in sodium and calcium.

The magnitude of the changes observed may be illustrated by reference to the 70 kilogram man. Skeletal weight in this individual would approximate 12 kilograms, according to the data of Shohl (32). A loss of $54 \mathrm{mEq}$. per kilogram from bone could, therefore, contribute $648 \mathrm{mEq}$. of sodium to the body fluids - the equivalent of more than 4 liters of extracellular fluid. This amount of fixed base could combine with nearly 6.5 liters of 0.1 normal anion. A similar calculation for potassium would give $122 \mathrm{mEq}$., equivalent to $800 \mathrm{ml}$. of intracellular water.

The lability of bone sodium observed in these experiments is relevant to the interpretation of electrolyte balance data. It is evident that sodium balances cannot always be considered only in terms of extracellular and intracellular water, since substantial amounts of excreted sodium may represent skeletal contributions. The data suggest that bone also participates in potassium exchange, though to a lesser degree. Whether either of these cations can be sequestered in bone to a significant extent during the administration of sodium and po- 
tassium salts is not yet known, though the possibility is apparent.

\section{SUMMARY AND CONCLUSIONS}

1. Average normal rat bone contains $152 \mathrm{mEq}$. of sodium and $26 \mathrm{mEq}$. of potassium per kilogram of fresh bone in excess of the amounts accounted for by extra- and intracellular fluid.

2. Rats depleted of sodium and made acidotic by intraperitoneal dialysis against ammonium chloride showed, within 48 hours, a decrease of bone sodium amounting to $42 \mathrm{mEq}$. per kilogram of bone and a decrease in potassium of $11 \mathrm{mEq}$. per kilogram. Changes in calcium were not proportionately large.

3. Rats raised on a synthetic sodium-free diet had bone sodium values $61 \mathrm{mEq}$. per kilogram below those of controls.

4. No obligatory ratio of either sodium or potassium to calcium was observed.

\section{REFERENCES}

1. Gamble, J. L., Ross, G. S., and Tisdall, F. F., The metabolism of fixed base during fasting. J. Biol. Chem., 1923, 57, 633.

2. Darrow, D. C., Da Silva, M. M., and Stevenson, S. S., Production of acidosis in premature infants by protein milk. J. Pediat., 1945, 27, 43.

3. Gamble, J. L., Wallace, W. M., Eliel, L., Holliday, M. A., Cushman, M., Appleton, J., Shenberg, A., and Piotti, J., Effects of large loads of electrolytes. Pediatrics, 1951, 7, 305.

4. Nichols, G., and Nichols, N., Jr., The availability of bone sodium. Clin. Res. Proc., 1953, $1,91$.

5. Flanagan, J. B., Davis, A. K., and Overman, R. R., Mechanism of extracellular sodium and chloride depletion in the adrenalectomized dog. Am. J. Physiol., 1950, 160, 89.

6. Gabriel, S., Chemische Untersuchungen über die Mineralstoffe der Knochen und Zähne. Ztschr. f. physiol. Chem., 1894, 18, 257.

7. Harrison, H. E., Darrow, D. C., and Yannet, H., The total electrolyte content of animals and its probable relation to the distribution of body water. J. Biol. Chem., 1936, 113, 515.

8. Kaltreider, N. L., Meneely, G. R., Allen, J. R., and Bale, W. F., Determination of the volume of the extracellular fluid of the body with radioactive sodium. J. Exper. Med., 1941, 74, 569.

9. Forbes, G. B., and Perley, A., Estimation of total body sodium by isotopic dilution. I. Studies on young adults. J. Clin. Invest., 1951, 30, 558.

10. Stern, T. N., Cole, V. V., Bass, A. C., and Overman, R. R., Dynamic aspects of sodium metabolism in experimental adrenal insufficiency using radioactive sodium. Am. J. Physiol., 1951, 164, 437.

11. Edelman, I. S., James, A. H., and Moore, F. D., Penetration of sodium and water into bone as measured with radiosodium and $\mathrm{D}_{2} \mathrm{O}$. Federation Proc., 1952, 11, 40.

12. Neuman, W. F., Neuman, M. W., Main, E. R., O'Leary, J., and Smith, F. A., The surface chemistry of bone. II. Fluoride deposition. J. Biol. Chem., 1950, 187, 655.

13. Bergstrom, W. H., The relationship of sodium and potassium to carbonate in bone. J. Biol. Chem., 1954, 206, 711.

14. Cotlove, E., Holliday, M. A., Schwartz, R., and Wallace, W. M., Effects of electrolyte depletion and acid-base disturbance on muscle cations. Am. J. Physiol., 1951, 167, 665.

15. Sunderman, F. W., and Williams, $P$., The analysis of chloride in tissues. J. Biol. Chem., 1933, 102, 279.

16. Wallace, W. M., Holliday, M., Cushman, M., and Elkinton, J. R., The application of the internal standard flame photometer to the analysis of biologic material. J. Lab. \& Clin. Med., 1951, 37, 621.

17. Kolthoff, I. M., and Sandell, E. B., Textbook of Quantitative Inorganic Analysis. New York, The Macmillan Co., 1936.

18. Halverson, J. O., and Bergeim, O., The determination of small amounts of calcium, particularly in blood. J. Biol. Chem., 1917, 32, 159.

19. Van Slyke, D. D., and Hiller, A., Application of Sendroy's iodometric chloride titration to proteincontaining fluids. J. Biol. Chem., 1947, 167, 107.

20. Hastings, A. B., and Sendroy, J., Jr., Studies of acidosis. XX. The colorimetric determination of blood $\mathrm{pH}$ at body temperature without buffer standards. J. Biol. Chem., 1924, 61, 695.

21. Van Slyke, D. D., and Neill, J. M., The determination of gases in blood and other solutions by vacuum extraction and manometric measurement. $I$. J. Biol. Chem., 1924, 61, 523.

22. Harrison, H. E., The sodium content of bone and other calcified material. J. Biol. Chem., 1937, 120, 457.

23. Hammett, F. S., A biochemical study of bone growth. I. Changes in the ash, organic matter, and water during growth (Mus norvegicus albinus). J. Biol. Chem., 1925, 64, 409.

24. Logan, M. A., Composition of cartilage, bone, dentin, and enamel. J. Biol. Chem., 1935, 110, 375.

25. Schwartz, R., Cohen, J., and Wallace, W. M., Tissue electrolyte changes of the whole body, muscle, erythrocyte and plasma of rats on a potassium deficient diet. Am. J. Physiol., 1953, 172, 1.

26. Irving, L., and Chute, A. L., The participation of the carbonates of bone in the neutralization of ingested acid. J. Cell. \& Comp. Physiol., 1932, 2, 157.

27. Donaldson, H. H., ed., The Rat; Data and Reference Tables for the Albino Rat (Mus norvegicus albinus) and the Norway Rat (Mus norvegicus). 2nd ed., 
rev., Philadelphia, 1924 (Memoirs of the Wistar Institute of Anatomy and Biology, no. 6).

28. Brooke, R. O., Smith, A. H., and Smith, P. K., Inorganic salts in nutrition. VII. Change in composition of bone of rats on a diet poor in inorganic constituents. J. Biol. Chem., 1934, 104, 141.

29. Sobel, A. E., Rockenmacher, M., and Kramer, B., Carbonate content of bone in relation to the composition of blood and diet. J. Biol. Chem., 1945, 158,475 .
30. Orent, E. R., Kruse, H. D., and McCollum, E. V., Studies on magnesium deficiency in animals. VI. Chemical changes in the bone, with associated blood changes, resulting from magnesium deprivation. J. Biol. Chem., 1934, 106, 573.

31. Duckworth, J., and Godden, W., The lability of skeletal magnesium reserves. The influence of rates of bone growth. Biochem. J., 1941, 35, 816.

32. Shohl, A. T., Mineral Metabolism. New York, Reinhold Publishing Co., 1939. 